\title{
Effects of a 20-Week Concurrent Training Program on Bone Metabolism in Elderly Women
}

\author{
Efecto de 20 Semanas de Entrenamiento Concurrente \\ Sobre el Metabolismo Óseo de Adultas Mayores
}

\begin{abstract}
Cristiano Andrade Quintão Coelho Rocha ${ }^{1}$; Andréa Carmen Guimarães²; Brisa D’Louar Costa Maia ${ }^{2}$; César Augusto Santos ${ }^{3}$; Maria Helena Rodrigues Moreira ${ }^{4}$; Estélio Henrique Martin Dantas; ${ }^{5}$ Paulina Yesica Ochoa-Martínez ${ }^{6}$; Javier Arturo HallLópez $^{6}$ \& Edgar Ismael Alarcón Meza ${ }^{6}$
\end{abstract}

ROCHA, C. A. Q. C.; GUIMARÃeS, A. C.; MAIA, B. D. C.; SANTOS, C. A.; MOREIRA, M. H. R.; DANTAS, E. H. M.; OCHOA-MARTÍNEZ, P. Y.; HALL-LÓPEZ, J. A. \& ALARCÓN, M. E. I. Effects of a 20-week concurrent training program on bone metabolism in elderly women. Int. J. Morphol., 36(2):655-660, 2018.

SUMMARY: The present study evaluated the effect of a 20-week concurrent training program on bone metabolism in elderly women. The sample consisted of 51 elderly women living in the municipality of Muriaé (MG), distributed into two groups: a concurrent training group $(\mathrm{CTG}=25)$, with an average age of $69.44 \pm 6.82$ years, and a control group $(\mathrm{CG}=26)$, with mean age of $68.30 \pm 6.34$ years. Biophysical parameters were determined based on weight, height and body mass index. Bone metabolism was assessed by collecting second-morning urine samples before and after intervention to analyze levels of the biochemical marker deoxypyridinoline (DPD), which quantifies bone resorption. Results: The results showed a post-intervention decline in DPD content in the GTC when compared to controls $(\mathrm{p}=0.007)$ and an improvement in the variables weight, BMI and DPD between the GTC and GC $(\mathrm{p}=0.000)$. Conclusion: Concurrent training was efficient in improving bone metabolism in the elderly population studied.

KEY WORDS: Aging; Physical training; Bone mineral content; Old people.

\section{INTRODUCTION}

Human aging is a multidimensional process that does not occur simultaneously throughout the body and is not necessarily associated with the presence of disease (Palácios \& Marchesi, 2014). It involves multiple endogenous and exogenous factors that must be considered together, especially in diagnostic situations. Biologically, a person reaches maturity or peak vitality between 25 and 30 years old, with the 25 to 40-year age range considered early adulthood; 40 to 65 years middle adulthood or middle age; 65 to 75 years early old age, and from 75 years onwards late old age (Palácios \& Marchesi).

Bone mass increases during childhood and early adulthood, peaking between the ages of 25 and 30 years. Approximately $10 \%$ of the skeleton remains active, undergoing continuous remodeling. A decline in estrogen after menopause means some women lose bone mass at a rate of 1 to $5 \%$ per year, reaching a $25 \%$ loss after 5 years, characterized as postmenopausal osteoporosis. Estrogen deficiency persists for up to 40 years after menopause (justifying the use of estrogen therapy in elderly patients), in addition to secondary hyperparathyroidism due to low calcium and vitamin $\mathrm{D}$ absorption in the late postmenopausal period (Garnero et al., 1999).

According to Vieira (1999), researchers in this field have long sought fast, reliable and practical laboratory techniques to assess bone metabolism. Thus, the use of biochemical markers of bone metabolism is vital to evaluate bone matrix formation and secretion.

Lopes et al. (2016) reported progressive biopsychosocial losses during aging, including a decline in organic functions, physical capacity and social levels that contributes to reduced physical activity (Rocha et al., 2015).

${ }^{1}$ Department of Physical Therapy. UniFaminas University Center (UNIFAMINAS), Brazil.

${ }^{2}$ Department of Physical Education and Health Sciences, Federal University of São João del-Rei (UFSJ), Brazil.

${ }^{3}$ Department of Medicine, São João del Rei Federal University (UFSJ), Brazil.

${ }^{4}$ Department of Sport Sciences, Exercise and Health. Trás-os-Montes e Alto Douro University (UTAD), Portugal.

${ }^{5}$ Biosciences Laboratory of Human Movement - LABIMH, University of Tiradentes (UNIT), Brazil.

${ }^{6}$ Faculty of Sports, Autonomous University of Baja California (UABC), México. 
ROCHA, C. A. Q. C.; GUIMARÃES, A. C.; MAIA, B. D. C.; SANTOS, C. A.; MOREIRA, M. H. R.; DANTAS, E. H. M.; OCHOA-MARTÍNEZ, P. Y.; HALL-LÓPEZ, J. A. \& ALARCÓN, M. E. I. Effects of a 20-week concurrent training program on bone metabolism in elderly women. Int. J. Morphol., 36(2):655-660, 2018.

The use of concurrent training as an alternative method is still recent in terms of health-related variables in the elderly population (Coelho-Farias et al., 2014). Adequate concurrent training can improve muscle structure and function in different age groups and clinical conditions, particularly among the elderly (Silva et al., 2014). However, scientific research on the effects of concurrent training is still insufficient to establish training criteria and discuss its influence on health promotion. Cadore et al. (2012) found that although several studies have been published on concurrent training, few address the elderly population.

As such, the present study aimed to assess the effects of a 20-week concurrent training program on bone metabolism in elderly women.

\section{MATERIAL AND METHOD}

This is an experimental study that investigates the cause-effect relationship between variables. The sample consisted of elderly women residing in the municipality of Muriaé, in Minas Gerais state (MG). The research project was disseminated using a folder, leaflets and lectures, whereby volunteers were given information on engaging in regular physical activity. Inclusion criteria were: women aged 60 years or older, who had not engaged in physical activity for at least 3 months and did not suffer from musculoskeletal disorders that might hamper their performance, execution of the exercises or the physical assessments. Elderly women who used medication that affects bone metabolism (glucocorticoids, immunosuppressants, anticonvulsants, corticotropin) and cardiovascular function (beta blockers and antiarrhythmics) were excluded from the study. The volunteers who met the criteria were randomly divided into a concurrent training group (CTG, $n=25$ aged 69.44 \pm 6.82 years) and control group (CG, $n=26$ aged $68.30 \pm 6.34$ years) that did not exercise during the study period.

The anthropometric variables assessed were weight (W) and height $(\mathrm{H})$, components of the body mass index $\left(\mathrm{BMI}=\mathrm{W} / \mathrm{H}^{2}\right)$. Weight was measured with subjects wearing as little clothing as possible (shorts and T-shirt) and their weight evenly distributed between their feet (Morrow Jr. et $a l ., 2014)$, standing in the center of a Filizola ${ }^{\circledR}$ (Brazil) mechanical balance. Height was assessed using an aluminum stadiometer fixed to the mechanical balance (Filizola ${ }^{\circledR}$ São Paulo, Brazil) and subjects were instructed to stand straight with their feet together and head in the Frankfurt plane while taking a deep breath. Height and weight were used to calculate the BMI of participants $\left[\mathrm{BMI}=\mathrm{W}(\mathrm{kg}) / \mathrm{Height}(\mathrm{m})^{2}\right]$. All the anthropometric measurements were obtained in accordance with International Standards for Anthropometric Assessment (Marfell-Jones et al., 2006). Individuals with $\mathrm{BMI}>24.9 \mathrm{~kg} / \mathrm{m}^{2}$ were classified as obese.

Bone metabolism was evaluated using a urine test for quantitative analysis of the urinary excretion of crosslinks of the biochemical bone resorption marker deoxypyridinoline (DPD) (Pardini et al., 2001). This peptide binds collagen molecules, specifically their amino and carboxyl terminals, and is released during bone resorption. It is primarily used as a marker of bone metabolism in osteoporosis, showing greater specificity in relation to other bone resorption markers.

To that end, $20 \mathrm{~mL}$ second-morning urine samples were collected and stored between $+2-+8^{0} \mathrm{C}$ during the collection period. Samples that were not sent for analysis on the day of collection were frozen at $-20^{\circ} \mathrm{C}$ and stored away from the light. Samples were analyzed by chemiluminescence (Elisa), generally within 24 hours of collection. The reference values used to assess the results were based on the sex and age of the subjects: women, 2.5 to $7.4 \mathrm{nmol} \mathrm{DPD} / \mathrm{mmol}$ creatinine.

The experimental group was submitted to concurrent training (CT), incorporating the variables muscle strength and cardiovascular endurance. The intervention consisted of an initial adaptation period followed by a specific training phase, totaling 20 weeks of concurrent training.

Muscle strength was determined according to participants' strength levels, whereby the maximum training load was calculated using maximal testing (Kim et al., 2002) for one repetition maximum (1RM), that is, $100 \%$ of the maximum load corresponded to one repetition maximum. The number of repetitions the subjects performed was based on the percentage load calculated for strength training. Strength training was carried out in 30-minute sessions three times a week and consisted of 3 sets of 8-10 repetitions, with 1 to 2 minutes' rests between sets and exercises and a maximum load between $70 \%$ and $85 \%$ of 1RM. The exercises performed were bilateral squats, bench press, leg extensions, lateral pulldowns, hamstring curls, bicep curls and stomach crunches, considered important in improving standing posture as well as upper and lower limb mobility. Equipment used included Barabani ${ }^{\circledR}$ dumbbells (Brazil); Physicus $^{\circledR}$ exercise equipment (Brazil) and Cepall ${ }^{\circledR}$ exercise mats (Brazil).

Intensity levels for cardiovascular endurance exercises were determined based on the heart rate reserve $(\mathrm{HRR}=$ maximum heart rate - resting heart rate $)$, with the maximum heart rate calculated according to the formula 
ROCHA, C. A. Q. C.; GUIMARÃES, A. C.; MAIA, B. D. C.; SANTOS, C. A.; MOREIRA, M. H. R.; DANTAS, E. H. M.; OCHOA-MARTÍNEZ, P. Y.; HALL-LÓPEZ, J. A. \& ALARCÓN, M. E. I. Effects of a 20-week concurrent training program on bone metabolism in elderly women. Int. J. Morphol., 36(2):655-660, 2018.

proposed by the American College of Sports Medicine (2014), as follows: $\mathrm{MHR}=206.9-(0.67 \mathrm{x}$ age $)$.

Cardiovascular endurance training took place three times a week in 30-minute sessions, with aerobic intensity between 70 and $89 \%$ of the reserve heart rate, using a 14 $\mathrm{cm}$-high step platform. The CT procedures applied were in line with ACSM recommendations (2014). The following movements were executed: basic step, V step, L step, side movements (knee lift, side kick, knee flexion, backward leg extension), arm movements (bicep curls and arm raises).

The concurrent training (CT) program applied was adapted from exercises in the Projeto Menopausa em Forma (Menopause in Shape Project), created by the Sports Department of Trás-os-Montes e Alto Douro University (UTAD).

Statistical treatment consisted of descriptive statistics using measures of central tendency (mean), dispersion (standard deviation) and inferential statistics, applying the Shapiro-Wilk test to assess normality. Intragroup comparisons were performed using the Wilcoxon test for independent samples (nonparametric), and the Student's ttest for dependent samples when needed. Intergroup comparisons used the Mann-Whitney test (nonparametric), and the Student's t-test for independent samples when necessary. The significance level for intra and intergroup comparisons was set at $\mathrm{p}<0.05$. The statistical procedures were performed using Statistical Package for the Social Sciences ${ }^{\circledast}$ software (SPSS 20.0).
The present study complied with guidelines for research involving human beings, governed by Brazilian National Health Council Resolution 466/2012 of 12/12/2012 (Ministério da Saúde, 2012; WMA, 2013). The study was approved by the Research Ethics Committee of Faculdade de Minas (FAMINAS), Muriaé campus (MG), under protocol number 250820141531.

\section{RESULTS}

The descriptive results of the anthropometric characteristics of the concurrent therapy (CTG) and control groups (CG) are shown in Table I. At the beginning of the study, the CTG exhibited lower weight $(-8.08 \mathrm{~kg}, \mathrm{p}=0.017)$ and BMI values $\left(-3.39 \mathrm{Kg} / \mathrm{m}^{2}, \mathrm{p}=0.008\right)$ compared to controls, with no differences observed in relation to height $(\mathrm{p}=0.405)$.

The descriptive results for deoxypyridinoline (DPD) levels in the concurrent training (CTG) and control groups (CG) are shown in Table II. The findings indicate that the CTG displayed similar DPD levels $(1.07, \mathrm{p}=0.865)$ when compared to the $\mathrm{CG}$ at the beginning of the study.

Table III shows the intra and intergroup comparisons of the biochemical marker deoxypyridinoline (DPD) in the two groups studied.

The results demonstrate a significant decline $(\mathrm{p}<0.05)$ in urinary DPD content in the CTG, while the CG showed

Table I. Pre- and post-intervention values for anthropometric variables in the two groups studied and comparison of pre-test means. Muriaé, MG, 2016.

\begin{tabular}{|c|c|c|c|c|c|}
\hline \multirow[b]{2}{*}{ Anthropometric variables } & \multicolumn{2}{|c|}{ Concurrent Training Group $(\mathrm{n}=25)$} & \multicolumn{2}{|l|}{ Control Group $(n=26)$} & \multirow{2}{*}{$\begin{array}{l}\text { Difference between } \\
\text { pre-test means }\end{array}$} \\
\hline & Pre-test Mean \pm SD & Post-test Mean \pm SD & Pre-t est Meana $\pm S D$ & Post-test Mean \pm SD & \\
\hline Weight $(\mathrm{kg})$ & $66.14 \pm 14.08$ & $65.02 \pm 13.91$ & $74.21 \pm 8.86$ & $76.35 \pm 9.07$ & $-8.08^{(\mathrm{a}) *}$ \\
\hline Height $(\mathrm{cm})$ & $156.16 \pm 0.05$ & $156.00 \pm 0.05$ & $155.00 \pm 0.05$ & $155.00 \pm 0.05$ & $0.01^{\text {(a) }}$ \\
\hline Body Mass Index $\left(\mathrm{kg} / \mathrm{m}^{2}\right)$ & $27.11 \pm 5.70$ & $26.65 \pm 5.62$ & $31.00 \pm 4.27$ & $31.88 \pm 4.27$ & $-3.89(\mathrm{a})^{*}$ \\
\hline
\end{tabular}

SD, standard deviation; Normality analyzed using the Shapiro-Wilk test; (a) T-test for independent samples. * p< 0.05 .

Table II. Pre- and post-intervention values for the biochemical marker deoxypyridinoline (DPD) in the two groups studied and comparison of pre-test means. Muriaé, MG, 2016.

\begin{tabular}{lccccc}
\hline \multirow{2}{*}{ Biochemical marker } & \multicolumn{2}{c}{ Concurrent Training Group $(\mathrm{n}=25)$} & Control Group $(\mathrm{n}=26)$ \\
Pre-test Mean \pm SD & Post-test Mean \pm SD & Pre-test Mean \pm SD & Post-test Mean \pm SD & $\begin{array}{l}\text { Difference between } \\
\text { pre-test means }\end{array}$ \\
\hline DPD & $9.80 \pm 4.32$ & $7.29 \pm 2.80$ & $8.73 \pm 2.18$ & $11.11 \pm 2.55$ & $1.07^{(\mathrm{a})}$ \\
\hline
\end{tabular}

DPD, Deoxypyridinoline; SD, standard deviation; Normality analyzed using the Shapiro-Wilk test; (a) Mann-Whitney test; * $\mathrm{p}<0.05$.

Table III. Intra and intergroup comparisons of deoxypyridinoline (DPD) levels in the two groups studied ( $\mathrm{p}$ values for hypothesis tests).

\begin{tabular}{lcccc}
\hline \multirow{2}{*}{ Biochemical Marker } & \multicolumn{2}{c}{ Intragroup } & \multicolumn{2}{c}{ Intergroup } \\
& CTG $(\mathrm{p})$ & $\mathrm{CG}(\mathrm{p})$ & Pre-test (p) & Post-test (p) \\
\hline DPD & $0.007^{(\mathrm{a}) \uparrow}$ & $0.000^{(\mathrm{a})^{\uparrow}}$ & $0.865^{(\mathrm{b})}$ & $0.000^{(\mathrm{c})^{*}}$ \\
\hline
\end{tabular}

DPD, Deoxypyridinoline; SD, standard deviation; Normality analyzed using the

Shapiro-Wilk test; (a) Mann-Whitney test; $* \mathrm{p}<0.05$. 
ROCHA, C. A. Q. C.; GUIMARÃES, A. C.; MAIA, B. D. C.; SANTOS, C. A.; MOREIRA, M. H. R.; DANTAS, E. H. M.; OCHOA-MARTÍNEZ, P. Y.; HALL-LÓPEZ, J. A. \& ALARCÓN, M. E. I. Effects of a 20-week concurrent training program on bone metabolism in elderly women. Int. J. Morphol., 36(2):655-660, 2018.

Table IV. Comparison of the percentage change (D) in deoxypyridinoline (DPD) content in the concurrent training (GTC) and control groups (CG).

\begin{tabular}{llll}
\hline Biochemical Marker & $\mathrm{CTG}(\mathrm{n}=25)$ Mean $\pm \mathrm{SD}$ & $\mathrm{CG}(\mathrm{n}=26)$ Mean $\pm \mathrm{SD}$ & $\mathrm{p}$-value \\
\hline DPD & $-16.74 \pm 36.08$ & $30.07 \pm 27.12$ & $0.000^{(\mathrm{a}) *}$ \\
\hline
\end{tabular}

DPD, Deoxypyridinoline; SD, standard deviation; Normality analyzed using the Shapiro-Wilk test; (a) Mann-Whitney test; * $\mathrm{p}<0.05$.

increased urinary DPD levels, indicating a significantly worse condition. Intragroup comparison demonstrated a significant post-test improvement in urinary DPD content $(\mathrm{p}=0.000)$ in the CTG when compared to controls.

Table IV shows a comparison of changes in deoxypyridinoline (DPD) content in the two groups assessed. The results demonstrate increased urinary deoxypyridinoline levels $(\mathrm{DPD}=30.07 \%)$ in the control group and a decline in DPD content $(\mathrm{DPD}=-16.74 \%)$ in the CTG.

\section{DISCUSSION}

A characteristic of our sample was the exclusive selection of postmenopausal women, although bone loss also affects elderly men. A significant amount of research has been conducted on elderly women, such as studies by Bassler \& Lei (2008), Monteiro et al. (2010), Monteiro et al. (2011) and Humphries et al. (2000).

Deoxypyridinoline is a biochemical marker of bone resorption and high levels are found in osteoporosis, Paget's disease of bone, bone metastases, hyperparathyroidism and hyperthyroidism (Kleerekoper, 2001). As such, it is widely used to assess bone loss due to its easy accessibility, applicability and cost-effectiveness.

Schroeder et al. (2004) studied musculoskeletal adaptations and efficacy in a progressive eccentric strength training program (16-week intervention). The sample consisted of 37 women divided into three groups, namely a high-intensity eccentric group, a low-intensity eccentric group and a control group. The results indicated a decline in deoxypyridinoline levels in the groups that performed high and low-intensity exercises. These findings corroborate those in the present study, whereby DPD concentration decreased in the CTG. Another noteworthy feature of the investigation by Schroeder $e t a l$. is the procedures applied for the biological material (urine) and biochemical marker (DPD), such as the collection of second-morning urine samples, the storage temperature of samples and the analyses technique used (ELISA), very similar to those applied here. With respect to training duration, Schroeder et al. observed that deoxypyridinoline levels in the high and low-intensity eccentric groups followed a similar trend, peaking in week 8 . By contrast, deoxypyridinoline declined significantly in the high-intensity eccentric group after 16 weeks of intervention.

Yu et al. (1998) analyzed deoxypyridinoline (DPD) in 51 healthy women divided into four groups: premenopausal women $(\mathrm{n}=10)$, postmenopausal women without osteoporosis or hormone replacement therapy (HRT) $(\mathrm{n}=14)$, postmenopausal women with osteoporosis and without HRT ( $\mathrm{n}=12)$ and postmenopausal women with HRT $(\mathrm{n}=15)$. The results demonstrated a significant difference in DPD concentration between pre- and postmenopausal women. Mean urinary DPD levels were significantly higher in postmenopausal women without treatment $(6.82 \pm 1.51$ $\mathrm{nmol} \mathrm{DPD} / \mathrm{mmol}$ of creatinine) than premenopausal women $(5.37 \pm 0.92 \mathrm{nmol} \mathrm{DPD} / \mathrm{mmol}$ of creatinine). However, there was no significant difference in urinary DPD between postmenopausal women without osteoporosis or HRT (6.82 $\pm 1.51 \mathrm{nmol} \mathrm{DPD} / \mathrm{mmolof}$ creatinine) and the postmenopausal participants with osteoporosis and without HRT (6.94 $\pm 2.32 \mathrm{nmol} \mathrm{DPD} / \mathrm{mmol}$ of creatinine). These data are similar to those recorded in the present study, since although our groups did not use HRT, similar postintervention DPD values were recorded in the CTG $(7.29 \pm 2.80 \mathrm{nmol} \mathrm{DPD} / \mathrm{mmol}$ of creatinine) and higher levels in the CG $(11.11 \pm 2.55 \mathrm{nmol} \mathrm{DPD} / \mathrm{mmol}$ of creatinine), with a significant intergroup difference in urinary DPD content. Although the mean DPD levels suggested by Yu et al. are similar to those observed here, the average age of participants in the postmenopausal group was lower (55.03) than that of our subjects.

Zhang et al. (2012) studied 85 elderly women with hip fractures, measuring the concentration of different biochemical markers, such as type I collagen, hydroxy terminal peptides (CrossLaps) and deoxypyridinoline (DPD). Another 60 patients without hip fractures were selected as controls. Urinary DPD levels were significantly higher in patients with hip fractures than controls, suggesting that individuals suffering from osteoporosis are more prone to hip fractures. Based on the above information, it is evident that sedentarism results in greater bone degeneration and may lead to osteoporosis and fractures. This highlights the importance not only of engaging in regular physical activity, but maintaining this habit in order to ensure better bone health. 
Humphries et al. studied 64 women aged between 45 and 65 years, divided into four different groups for a $24-$ week intervention: strength training with HRT, strength training without HRT, walking with HRT, and walking without HRT, using the biochemical markers osteocalcin and deoxypyridinoline. The authors concluded that osteocalcin increased in the group submitted to walking without HRT. One year later, the same authors analyzed 116 elderly women with the same age range and training characteristics applied in the previous investigation (Humphries et al.), using osteocalcin and deoxypyridinoline. The results indicated increased osteocalcin levels in the walking without HRT group. These findings suggest that training alone does not produce satisfactory results in terms of bone resorption. The training methodology applied here was different to that used by Humphries et al. It seems that the use of a training program that combines muscular strength and endurance exercises is essential to increase bone mineral density. However, additional factors should be considered in order to promote more satisfactory results, including the type of exercises performed and the use of predetermined variables such as the intensity, volume and duration of training.

Vincent \& Braith (2002) demonstrated a relationship between variations in the level of bone metabolism markers and bone density changes, also identifying a relation between training intensity and the magnitude of increases in bone formation markers (bone-specific alkaline phosphatase and osteocalcin) and decreased pyridinoline content (bone resorption marker). Several other authors (Pernambuco et al., 2013; Hall-López et al., 2014; Bandeira et al., 2014; Moreira et al., 2014a,b) have reported a greater response by bone formation markers to high-intensity training.

Ochoa-Martínez et al. (2015) assessed the effect of a three-month water aerobics program on deoxypyridinoline levels in 26 elderly women divided into an intervention group $(n=16)$ and a control group $(n=10)$. The intervention group was submitted to 12 weeks of water aerobics, five times a week in 50-minute sessions, gradually increasing the resting heart rate. Comparison of urinary deoxypyridinoline content $(p=0.504)$ showed no significant intergroup improvements $(\mathrm{p}<0.05)$. However, the percentage variation $(\Delta \%)$ indicated an improvement of -13.7 (nmol DPD/mmol creatinine) in the experimental group compared to -7.1 (nmol DPD/mmol creatinine) in controls. Although the exercises performed differed from the present study, the results corroborate our data since the concurrent training group exhibited a postintervention variation of- 16.74 (nmol DPD/mmol creatinine).

General limitations of the variables analyzed include the fact that socioeconomic status and eating habits were not addressed. Additionally, interactions may have occurred with uncontrolled medication during the study. However, it is important to underscore that women who used glucocorticoids, immunosuppressants, anticonvulsants, corticotropins, beta blockers and antiarrhythmics were excluded from the study. Although several studies have demonstrated the efficiency of concurrent training in improving different physiological functions among young and middle-aged populations, few have focused on the elderly. Another factor to consider pertains to the adaptations made to the physical training of the elderly participants, whereby loads should have been adjusted during the intervention phase. Thus, further research is recommended to assess these intervening variables.

A concurrent training program aimed at improving muscle strength and cardiovascular endurance was vital to maintain/improve weight and BMI and reduce urinary deoxypyridinoline (DPD) levels.

Changes in behavioral patterns, such as hormone replacement therapy, better eating habits and engaging in regular physical activity seem to significantly influence the reduction of DPD content, that is, the elderly population must implement these practices in order to improve their physical health and bone mineral density, making them less vulnerable to diseases that compromise bone metabolism.

ROCHA, C. A. Q. C.; GUIMARÃES, A. C.; MAIA, B. D. C.; SANTOS, C. A.; MOREIRA, M. H. R.; DANTAS, E. H. M.; OCHOA-MARTÍNEZ, P. Y.; HALL-LÓPEZ, J.A. \& ALARCÓN, M. E. I. Efecto de 20 semanas de entrenamiento concurrente sobre el metabolismo óseo de adultas mayores. Int. J. Morphol., 36(2):655$660,2018$.

RESUMEN: El presente estudio evaluó los efectos de 20 semanas de entrenamiento concurrente sobre el metabolismo óseo de adultas mayores. La muestra fue compuesta por 51 mujeres adultas mayores, residentes en el municipio de Muriaé (MG), voluntarias, distribuidas en dos grupos, un grupo participó en entrenamiento concurrente $(\mathrm{GTC}=25)$, con una edad media de $69,44 \pm 6,82$ años y

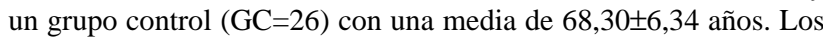
parámetros biofísicos se determinaron por medio del peso corporal, la estatura e índice de masa corporal. Para la evaluación del metabolismo óseo, se realizó la recolección de la orina matinal en el pre y post-test, utilizando como reactivo el marcador bioquímico de deoxipiridinolina (DPD) que cuantifica la reabsorción ósea. Los resultados mostraron una reducción en la concentración de DPD en el GTC cuando se compararon los grupos $(\mathrm{p}=0,007)$ y la mejora de las variables, peso corporal, IMC y DPD entre el GTC y el GC en el post-test $(\mathrm{p}=0,000)$. Se percibe que el entrenamiento concurrente, para las mujeres adultas mayores fue eficiente en la mejoría de las condiciones de salud del metabolismo óseo.

PALABRAS CLAVE: Envejecimiento; Entrenamiento físico; Contenido mineral óseo; Adulto Mayor. 


\section{REFERENCES}

American College Sports Medicine. Guidelines for Exercise Testing and Prescription. 9 $^{\text {th }}$ ed. Rio de Janeiro, Guanabara, 2014.

Bandeira, F.; Costa, A. G.; Soares Filho, M. A.; Pimentel, L.; Lima, L. \& Bilezikian, J. P. Bone markers and osteoporosis therapy. Arq. Bras. Endocrinol. Metabol., 58(5):504-13, 2014.

Bassler, T. C. \& Lei, D. L. M. Diagnóstico e monitoramento da situação nutricional da população idosa em município da região metropolitana de Curitiba (PR). Rev. Nutr. Campinas, 21(3):311-21, 2008.

Cadore, E. L.; Izquierdo, M.; Alberton, C. L.; Pinto, R. S.; Conceição, M.; Cunha, G.; Radaelli, R.; Bottaro, M.; Trindade, G. T. \& Kruel, L. F. Strength prior to endurance intra-session exercise sequence optimizes neuromuscular and cardiovascular gains in elderly men. Exp. Gerontol., 47(2):164-9, 2012.

Coelho-Farias, M.; Borba-Pinheiro, C.; Oliveira, M. \& Vale, R. G. S. Efectos de un programa de entrenamiento concurrente sobre la fuerza muscular, flexibilidad y autonomía funcional de mujeres mayores. Rev. Cienc. Act. Fis., 15(2):13-24, 2014.

Garnero, P.; Tsouderos, Y.; Marton, I.; Pelissier, C.; Varin, C. \& Delmas, P. D. Effects of intranasal 17beta-estradiol on bone turnover and serum insulin-like growth factor I in postmenopausal women. J. Clin. Endocrinol. Metab., 84(7):2390-7, 1999.

Hall-López, J. A.; Ochoa-Martínez, P. Y.; Alarcón-Meza, E. I.; AnayaJaramillo, F. I.; Teixeira, A. M. M. B.; Moncada-Jiménez, J.; FerreiraReis, J. C. \& Dantas, E. H. M. Effect of a hydrogymnastics program on the serum levels of high-sensitivity C-reactive protein amongst elderly women. Health, 6(1):80-5, 2014.

Humphries, B.; Newton, R. U.; Bronks, R.; Marshall, S.; McBride, J.; Triplett-McBride, T.; Käkkinen, K.; Kraemer, W. J. \& Humphries, N. Effect of exercise intensity on bone density, strength, and calcium turnover in older women. Med. Sci. Sports Exerc., 32(6):1043-50, 2000.

Kim, P. S.; Mayhem, J. L. \& Peterson, D. F. A modified YMCA bench press test as a predictor of 1 repetition maximum bench press strength. J. Strength Cond. Res., 16(3):440-5, 2002.

Kleerekoper, M. Biochemical markers at bone turnover: why teary, research, and clinical practice are still in conflict. Clin. Chem., 47:1347-9, 2001.

Lopes, M. A.; Krug, R. R.; Bonetti, A. \& Mazo, G. Z. Barreiras que influenciaram a não adoção de atividade física por longevas. Rev. Bras. Cienc. Esporte, 38(1):76-83, 2016

Marfell-Jones, M.; Olds, T.; Stewart, A. \& Carter, L. International Standards for Anthropometric Assessment. Potchefstroom, International Society for the Advancement of Kinanthropometry, 2006.

Ministério da Saúde. Resolução 466/12. O Plenário do Conselho Nacional de Saúde resolve aprovar diretrizes e normas regulamentadoras de pesquisas envolvendo seres humanos. Brasilia, Ministério da Saúde da Brasil, 2012.

Monteiro, M. A.; Gabriel, R. E.; Sousa, M. F.; Abrantes, J. M. \& Moreira, M. H. Impact of a 12-month exercise program on the temporal parameters of the foot rollover during walking in postmenopausal women. Menopause, 17(5):1017-25, 2011.

Monteiro, M. A.; Gabriel, R. E.; Sousa, M. F.; Arantes, J. M. \& Moreira, M. H. Impact of a 12-month exercise program on the temporal parameters of the foot rollover during walking in postmenopausal women. Menopause, 18(7):771-7, 2010.

Moreira, L. D.; Fronza, F. C.; Dos Santos, R. N.; Zach, P. L.; Kunii, I. S.; Hayashi, L. F.; Teixeira, L. R.; Kruel, L. F. \& Castro, M. L. The benefits of a high-intensity aquatic exercise program (HydrOS) for bone metabolism and bone mass of postmenopausal women. J. Bone Miner. Metab., 32(4):411-9, 2014a.

Moreira, L. D.; Oliveira, M. L.; Lirani-Galvão, A. P.; Marin-Mio, R. V.; Santos, R. N. \& Lazaretti-Castro, M. Physical exercise and osteoporosis: effects of different types of exercises on bone and physical function of postmenopausal women. Arq. Bras. Endocrinol. Metabol., 58(5):514$22,2014 \mathrm{~b}$
Morrow Jr., H. R.; Jackson, A. W.; Disch, J. G. \& Mood, D. P. Medida e Avaliação do Desempenho Humano. $4^{\text {th }}$ ed. Porto Alegre, Artmed, 2014.

Ochoa-Martínez, P. Y.; Hall-Lopez, J. A.; Ávila, F. A.; Rocha, C. A.; Moreira, M. H. \& Dantas, E. H. Effect of three months of periodized hydrogymnastics exercise program on urinary concentration of deoxypyridinoline in older women. Arch. Endocrinol. Metab., 59(6):523-7, 2015.

Palácios, J. \& Marchesi, A. Mudança e Desenvolvimento Durante a Idade Adulta e a Velhice: Desenvolvimento Psicológico e Educação Psicologia Evolutiva. Porto Alegre, Artmed, 2014.

Pardini, R.; Matsudo, S.; Araújo, T.; Matsudo, V.; Andrade, E.; Braggion, G.; Andrade, D.; Oliveira, L.; Figueira Jr., A. \& Raso, V. Validação do questionário internacional de nível de atividade física (IPAQ - versão 6): estudo piloto em adultos jovens brasileiros. Rev. Bras. Cienc. Mov., 9(3):45-51, 2001.

Pernambuco, C. S.; Borba-Pinheiro, C. J.; Vale, R. G.; Di Masi, F.; Monteiro, P. K. \& Dantas, E. H. Functional autonomy, bone mineral density (BMD) and serum osteocalcin levels in older female participants of an aquatic exercise program (AAG). Arch. Gerontol. Geriatr., 56(3):466-71, 2013.

Rocha, C. A. Q. C.; Moreira, M. H. R.; Mesa, E. I. A.; Guimarães, A. C.; Dória, C. H. \& Dantas, E. H. M. Efeitos de um programa de treinamento concorrente sobre a autonomia funcional em idosas pós-menopáusicas. Rev. Bras. Cienc. Mov., 23(3):122-34, 2015.

Schroeder, E. T.; Hawkins, S. A. \& Jaque, S. V. Musculoskeletal adaptations to 16 weeks of eccentric progressive resistance training in young women. J. Strength Cond. Res., 18(2):227-35, 2004.

Silva, N. L.; Oliveira, R. B.; Fleck, S. J.; Leon, A. C. \& Farinatti, P. Influence of strength training variables on strength gains in adults over 55 yearsold: a meta-analysis of dose-response relationships. J. Sci. Med. Sport, 17(3):337-44, 2014

Vieira, J. G. H. Considerações sobre os marcadores bioquímicos do metabolismo ósseo e sua utilidade prática. Arq. Bras. Endocrinol. Metab., 43(6):415-22, 1999

Vincent, K. R. \& Braith, R. W. Resistance exercise and bone turnover in elderly men and women. Med. Sci. Sports Exerc., 34(1):17-23, 2002.

World Medical Association (WMA). WMA Declaration of Helsinki: Ethical Principles for Medical Research Involving Human Subjects. Fortaleza, World Medical Association, 2013.

Yu, S. L.; Ho, L. M.; Lim, B. C. \& Sim, M. L. Urinary deoxypyridinoline is a useful biochemical bone marker for the management of postmenopausal osteoporosis. Ann. Acad. Med. Singapore, 27(4):5279, 1998.

Zhang, Z. Y.; Hou, X. H.; Xie, G. Y.; Sun, X. W. \& Xue, L. Relationship between elderly hip fracture and osteoporosis. Zhonghua Liu Xing Bing Xиe Za Zhi, 33(12):1293-5, 2012.

Corresponding author:

Javier Arturo Hall-López

Faculty of Sports

Autonomous University of Baja California (UABC)

MÉXICO

Email: javierhall@uabc.edu.mx

Recibido : 19-09-2017

Aceptado: 02-01-2018 